\section{Jurandir Malerba}

Professor no Departamento de História da Pontifícia Universidade

Católica do Rio Grande do Sul (FFCH/PUC-RS - Porto Alegre/Brasil) e-mail: jurandir.malerba@pucrs.br
JESUS, Ronaldo Pereira de.

Visões da Monarquia. Escravos, operários e Abolicionismo na Corte. Belo Horizonte: Argvmentvm, 2009. 216p.

\section{Vossa Alteza, vista cá debaixo}

Os estudos sobre a sociedade imperial do Brasil baseados em critérios de estratificação social de classe, desde sempre, é fato, ressoavam as concepções de mundo das classes dirigentes ou "dominantes", ou "superiores". Tal se dava seja porque se enaltecia, num primeiro momento, a "obra virtuosa" de edificação da Nação-Estado monárquica levado a cabo por sua diligente elite política; seja, depois, devido à análise crítica do papel dessas mesmas elites imperiais e sua obra: 1) a edificação do aparato jurídico do Estado pelos homens de letra e lei imperiais, consubstanciada em seus diplomas magnos que são a Constituição de 1824, o Código Criminal de 1830, o do Processo Criminal de 1832 e o Código Comercial de 1850; 2) a construção de uma identidade nacional, costurada em ponto-cruz pelos artistas, com grande peso dos escritores, sob a luz romântica do século (aqui, de nosso romantismo indianista); e e 3) a direção política da máquina governamental, em particular durante o segundo reinado, sob a tutela da indefectível mão paternal do summa potestas imperial.

Pelo menos desde os anos 1980, porém, sob influência da recepção das diversas matrizes do que se batizou de history from Below ou history from the bottom up, em particular da história social britânica de E. P. Thompson e Eric Hobsbawm mas igualmente de outras vertentes da história cultural que têm as camadas populares como sujeitos privilegiados de análise, como a micro-história italiana, os historiadores brasileiros procuraram expandir os horizontes das concepções ou visões de mundo constitutivas dessa heterogênea sociedade brasileira do século XIX, um mosaico complexo e que se torna complexo devido à sobreposição de critérios de identidade dos indivíduos, que misturam elementos de caráter jurídico (escravos, forros, livres), de caráter político (baseada em padrões censitários como cidadãos ativos, não-ativos e não-cidadãos), de estratificação social de classe (escravos, senhores, trabalhadores livres), de estratificação social de ordem (religiosos, militares aristocratas, trabalhadores), e, como ainda acontece no Brasil errante de hoje, critérios de identidade étnica (pretos, brancos, índios, pardos (?)). Em verdade, essa historiografia renovadora que surgiu nos anos 1980 foi mais bem sucedida quando identificou seus sujeitos (não ousaria dizer aqui "objetos") de estudo a partir de critérios de estratificação de classe, nomeadamente os escravos no século XIX. Nomes justamente conspícuos, modelares de nossa historiografia, como Kátia Mattoso, João José Reis, Eduardo Silva, Silvia Hunold Lara, Luiz Geraldo Silva, Manolo Florentino e tantos outros aqui deram e dão enorme contribuição. Porém, a rigor, não me vem à mente estudo bem sucedido quando aqueles critérios se diluem, trabalho que resta por fazer.

0 livro de Ronaldo Pereira de Jesus soma-se a esse esforço coletivo de nossa historiografia no sentido do resgate dos modos de ver a instituição monárquica e a figura do imperador de uma perspectiva from below, do ponto de vistas das camadas populares. Este talvez seja um dos grandes desafios que não apenas Ronaldo Pereira, mas todos os pesquisadores que 
compartilham desta perspectiva enfrentam, ou seja, a definição criteriosa do que se encontra below: entre vários, o autor opera com termos como "população pobre", "classes populares", "camadas populares", "gente comum", "povo", "setores subalternos" (no prefácio ao livro, Sidney Chalhoub fala da "gente miúda"). A composição desse segmento só pode ser abrangente, para conter "o setor mais diretamente ligado ao cativeiro, composto por escravos e libertos, negros e mulatos" (p.10). A estes se somam os "homens livres pobres (miseráveis, mendigos, 'vadios' ou 'desclassificados')". Devem compor a "gente comum", ainda, pequenos comerciantes, artesãos, "executores de ofícios indignos", militares de baixa patente, funcionários públicos de baixo escalão e operários. Por certo que há subjacente um desafio metodológico. As "elites", por mais ambíguo que seja este conceito mesmo, deixaram registros de sua experiência. 0 investigador pode mesmo nomear os membros das elites (sejam estas elites políticas, intelectuais, econômicas ou qualquer outro recorte); pode agrupá-los, pode resgatar sua rede de relações. Há tanto documentação como metodologia para isso (prosopografia, por exemplo). Trata-se daquela famosa metáfora brechteana: sabemos quase tudo do faraó de tal pirâmide, mas muito pouco dos escravos que a levantaram. De modo que as visões de mundo dessas classes subalternas chegam-nos muita vez enviesadas, por terem sido registradas pelos vencedores e produtores da memória oficial.

Porém subjazem aí, também, duas questões de ordem teórica: primeiramente, no que tange ao caráter generosamente inclusivo desse conceito de "pessoas comuns". Compartilhariam todos aqueles segmentos das mesmas visões da monarquia? Em segundo lugar, não obstante o autor expressar sua opção pela análise da diferenciação social de classes e da dinâmica da relação entre elas, ao evocar a brilhante análise da "dialética da malandragem" de Antonio Candido sobre os três mundos (do trabalho, da ordem e da desordem) que justamente ordenavam o universo social das Memórias de um sargento de milícias, o autor ancora sua análise numa estrutura teórica que concebe a sociedade escravista monárquica em sua divisão em ordens e não em classes. 0 que, a meu ver, é efetivamente mais profícua para seus propósitos e lhe oferece bons frutos, ainda que persista a tensão conceitual.

Muito sagaz e bem realizada é a forma como Ronaldo Pereira de Jesus estruturou sua pesquisa e construiu sua narrativa. Depois de uma exaustiva recensão bibliográfica, as visões da monarquia, do monarca e do governo imperial (que muitas vezes se confundem), foram criteriosamente pesquisadas em diversos e complementares fundos documentais. Dentro do sistema paternalista em que se erigia a monarquia brasileira, os súditos recorriam à coroa para todo tipo de benefício pessoal. Num universo imenso de súplicas dirigidas ao monarca para obtenção de todo tipo de graça (prática comum desde o reinado de D. João e mesmo antes, na história da monarquia portuguesa), o autor coligiu as súplicas dirigidas ao monarca pelas pessoas comuns, lavradas cunho próprio ou por terceiros. Em seguida, procurou depurar aquelas visões da monarquia inscritas nas homenagens dirigidas à Coroa por inúmeras corporações de ofício e associações profissionais, de classe ou beneficentes (de auxílio mútuo, por categorias sócioeconômicas). Aqui, o autor sugere a existência do movimento de um proto-operariado organizado e portador de uma consciência de classe que, sábia de seus direitos, pugnava por estes direitos junto ao Estado (por isso, com Fausto, denomina-o "estatista"), desenvolvendo "práticas de contes- 
tação aliadas a uma discursividade radical ao longo da segunda metade do século XIX" (p.96).

As visões da monarquia são perscrutadas, em seguida, em três movimentos importantes do Segundo Reinado, como são a Revolta do Vintém, o Abolicionismo e os impactos da Abolição da escravidão propriamente dita sobre as visões da gente comum sobre a realeza. Um dos capitulos mais saborosos do livro, a narrativa sobre a Revolta do Vintém permite ao autor perceber uma alteração de percepção da monarquia, de protetora e paternal para sua crítica contumaz, que chega à mobilização coletiva e violenta, ao gosto dos riots estudados por Rudé e Hobsbawm. Para o autor, a Revolta do Vintém ensejou mesmo a "alteração radical e momentânea das atitudes e expectativas diante do regime político e do imperador", mais do que "uma mudança significativa e duradoura no imaginário popular e nas representações das pessoas comuns acerca da Monarquia. A recuperação da participação popular (singela!) no movimento abolicionista, levada a cabo nas conferências realizadas na Corte nos momentos decisivos da campanha (1885-1887), nos festivais abolicionistas e na mobilização efetivamente popular consiste numa das grandes contribuições de toda a obra. Embora constatando que o Abolicionismo, como movimento formador de opinião pública, foi definitivamente um movimento de elite, o autor conclui "supondo que a profusão de imagens negativas do imperador e do regime monárquico abalou consideravelmente as percepções positivas do imperador e da monarquia entre as pessoas comuns da corte" (p.163). Porém, independentemente dessa gradação valorativa e essa é a tese recorrente do livro, para além dela subsistiria entre a gente comum da corte "o pragmatismo, a indiferença e o afastamento de sempre". Ou seja, as pessoas comuns pouco se deixavam "contaminar" pelas visões positivas da monarquia e do monarca, como "pai dos pobres", benevolente e justo estas sim imagens difundidas pelas camadas dominantes. Assim também, pouco alteraria o quadro a "outorga" da libertação dos escravos pela Princesa Izabel, já que todas as festas da abolição foram manifestações públicas das classes escravistas e de setores médios urbanos, expressões de "alívio e entusiasmo por não mais habitar um país escravista" (p.173). 0 povo, a gente comum, não foi senão espectador nessa festa. Espectador bilontra, mas espectador.

Afora pouquíssimos ruídos de edição, o texto de Ronaldo Pereira de Jesus é muito bem cuidado, bem escrito, prazeroso. Seu livro expressa mais uma contribuição séria e bem executada deste importante setor da historiografia brasileira que se dedica a escrever a história daqueles sujeitos que foram insistentemente esquecidos por ela. 